\title{
Fungal content and activities in standing-decaying leaf blades of plants of the Georgia Coastal Ecosystems research area
}

\author{
Steven Y. Newell* \\ Marine Institute, University of Georgia, Sapelo Island, Georgia 31327, USA
}

\begin{abstract}
Change in salinity, including expansion or contraction of salt- and freshwater marshes, due to altered river outflow may influence a variety of ecosystem processes, and the literature to date suggests that fungal activity in standing-decaying blades of macrophytes may be lower in freshwater marshes than in saltmarshes. I measured living-fungal mass (as ergosterol), rate of $\mathrm{CO}_{2}$ evolution, and rate of fungal membrane synthesis (acetate incorporation into ergosterol) for standing-decaying blades from a series of macrophytes, including saltmarsh cordgrass in both saline and fresher-water sites. Three terrestrial plants with prominent standing-decaying leaf blades were included for comparison. Species involved were: Spartina alterniflora, S. cynosuroides, Zizaniopsis miliacea, Typha angustifolia, Sabal palmetto, Uniola paniculata, and Panicum amarum. Although there was no difference in fungal content of $S$. alterniflora blades from saltier and fresher sites, there was a significant trend downwards (from $>500$ to $<250 \mu \mathrm{g}$ ergosterol $\mathrm{g}^{-1}$ system organic mass) in mean content of living-fungal mass moving from saltmarsh-adapted toward freshwater-adapted plants, and 2 of 3 terrestrial plants were also low (ca. $\left.100 \mu \mathrm{g} \mathrm{g}^{-1}\right)$. The activity measurements $\left(\mathrm{CO}_{2}\right.$, acetate incorporation) revealed an opposite pattern: blades from fresher-water plants had higher activities per unit livingfungal mass (range of about 4 -fold for mean rate of acetate incorporation per unit ergosterol), and lower $\mathrm{CO}_{2}$ release per unit fungal membrane synthesis, than did more saline-adapted plants. It is proposed that this is perhaps largely a consequence of the microstructure (lignification, cuticular hydrophobicity) of the blades of the fresher-water plants (and 2 of the terrestrial plants) limiting duration of fungal activity. Upon thorough wetting, such as eventually occurs when blades move to the marsh-sediment surface, fungi within the fresher-water blades would be permitted to grow quickly, which would explain reported increases in ergosterol content of fallen blades.
\end{abstract}

KEY WORDS: Fungal biomass - Fungal productivity $\cdot \mathrm{CO}_{2}$ release $\cdot$ Standing decay $\cdot$ Ergosterol $\cdot$ Saltmarsh · Freshwater marsh · Altamaha River

Resale or republication not permitted without written consent of the publisher

\section{INTRODUCTION}

Fungal productivity is a key component of secondary production in the saltmarshes of Georgia (Newell \& Porter 2000). The major photosynthetic producing agent in these marshes, smooth cordgrass Spartina alterniflora, holds its leaves and stems in place after death (i.e. the leaves and stems are not abscised), so decay begins in the attached state. Ascomycetous fungi take advantage of this situation (Buchan et al. 2002, Kohlmeyer \& Volkmann-Kohlmeyer 2002,
Newell 2002), and accumulate substantial biomasses in the standing-decaying shoots. Average livingfungal biomasses (using ergosterol content as a proxy; Newell 2001b, Gessner \& Newell 2002) in smooth cordgrass leaf blades over a 3 yr period ranged from 292 (summer) to 554 (spring) $\mu \mathrm{g}$ ergosterol $\mathrm{g}^{-1}$ organic mass of the decay system, equivalent to a living-fungal mass of about 6 to $11 \%$ of blade organic mass (Newell 2001a). The mean rate of annual fungal organic-mass production was found to be $535 \mathrm{~g} \mathrm{~m}^{-2}$ marsh (production:biomass $\approx 10: 1$ ), based on measured rates of 
acetate incorporation into ergosterol (Newell 2001a). This substantial fungal productivity is consistent with findings of high rates of animal outflow associated with Georgia saltmarshes (Turner \& Boesch 1988, Kneib 2000, Teal \& Howes 2000, Zimmerman et al. 2000), and with accumulating evidence of fungal input into the marsh foodweb (e.g. Graça et al. 2000).

The high rates of fungal production per unit decaysystem mass found for smooth cordgrass contrast sharply with rates found using the same techniques during cold and warm seasons for a freshwater sedge (Carex walteriana, Walter's sedge) (1 technique difference: $20^{\circ} \mathrm{C}$ incubation for cordgrass and $25^{\circ} \mathrm{C}$ for sedge; Newell et al. 1995). The maximum mean rate of fungal production for standing-decaying blades of Walter's sedge (using the same conversion factors from acetate incorporation from Newell 2001a) was approximately equal to the lowest mean value found for smooth cordgrass (about $70 \mu \mathrm{g}$ fungal organic mass $\mathrm{g}^{-1}$ system organic mass $\mathrm{h}^{-1}$ ), and was about one-fifth of the maximum mean value for smooth cordgrass (329 $\mathrm{\mu g} \mathrm{g}^{-1} \mathrm{~h}^{-1}$ ) (Newell 2001a). Though both wetland plants exhibited higher ergosterol contents in cold rather than warm months, mean content of ergosterol in standing-decaying blades of the freshwater sedge was also distinctly lower than that for smooth cordgrass (113 to $187 \mu \mathrm{g} \mathrm{g}^{-1}$ organic mass of decay system vs 292 to $554 \mathrm{\mu g} \mathrm{g} \mathrm{g}^{-1}$ ). Ergosterol contents of standingdecaying blades were also higher for a saltmarsh rush (Juncus roemerianus, black needlerush, 259 to $308 \mu \mathrm{g}$ $\mathrm{g}^{-1}$ ) than for the freshwater sedge at a similar stage of decay (Newell 2001c).

The contrast in fungal accumulation found between freshwater sedge and saltmarsh macrophytes prompted us to design a survey of coastal plants with standing-decaying leaves: would there be a consistent pattern of high ergosterol content and fungal productivity for saltmarsh plants relative to freshwater plants and terrestrial plants? Answering this question also fits into the objectives of the Georgia Coastal Ecosystem Long Term Ecological Research (GCE/LTER) program (see 'Acknowledgements') — what might be the effects of lower river flow from the Altamaha River, and resultant increases in salinity of coastal and river-mouth marshes (see e.g. Scavia et al. 2002)?

\section{MATERIALS AND METHODS}

Plants sampled. All plants sampled have prominent standing-decaying stages for their leaf blades, and are common and widespread in coastal Georgia (Duncan \& Duncan 1987, Tiner 1993). The central focus was on 3 marsh grasses, ranging from very salt-adapted (Spartina alterniflora, smooth cordgrass), through brackish-water-adapted (S. cynosuroides, big cordgrass), to freshwater-adapted, but low-salinity-tolerant (Zizaniopsis miliacea, giant cutgrass). In addition, 2 plants common near Georgia's saltmarshes, a freshwater grasslike plant (Typha angustifolia, narrowleaved cattail) and a palm (Sabal palmetto, cabbage palm) were sampled, as were 2 common beach-dune grasses (Uniola paniculata, sea oats, and Panicum amarum, seaside panicum).

Sites. All sites were within the GCE/LTER rectangle (approximate boundaries: $81^{\circ} 10^{\prime}$ to $81^{\circ} 35^{\prime} \mathrm{W}, 31^{\circ} 18^{\prime}$ to $31^{\circ} 33^{\prime} \mathrm{N}, \approx 540 \mathrm{~km}^{2}$ ). This rectangle contains 3 transects running from landward stations eastward to seaward stations; Sapelo Island is entirely within the rectangle. The southern transect (Stns 7 to 9) runs from a station that is in nearly entirely freshwater marshes, about $20 \mathrm{~km}$ upriver, to a station at the mouth of the Altamaha River surrounded by saltmarsh. The middle transect runs from a station in saltmarsh bordering Hudson Creek (Stn 4) on the mainland eastward through Doboy Sound to Stn 6 in saltmarshes of SE Sapelo Island. The northerly transect runs from saltmarshes adjoining the Sapelo River (Stn 1) on the mainland eastward to saltmarsh at the north end of Sapelo Island (Stn 3). Extensive descriptions of these stations, including maps and salinities, are presented on the GCE/LTER website (http://gce-lter.marsci.uga. edu/lter/); see also Smith et al. (2001).

The 2 sites used for collections of naturally decaying leaf blades of each species (or species $\times$ salinity) sampled were as follows. For smooth cordgrass, sites were chosen at the 4 corners of the GCE/LTER rectangle, to encompass the wide range of salinities of the area's waters. The 2 fresher sites were Stn 1 (salinities approximately 25 to 28 psu during dry periods, but near zero during, and for days following, periods of heavy rain) and a site $3.5 \mathrm{~km}$ east of Stn 7 (Champney Park on the Altamaha River, salinities near zero to the high single digits; there is only a thin [ $<2 \mathrm{~m}$ wide] strip of smooth cordgrass at the river's edge at this site). The 2 saltier sites were Stn 6 on the SE edge and Stn 3 on the northern end of Sapelo Island (salinity range 23 to $34 \mathrm{psu}$ ). For giant cutgrass, 2 subsites at the Champney Park site were used, at the river's edge, and at a site $50 \mathrm{~m}$ back away from the river (this site is dominated by giant cutgrass marsh). For big cordgrass, the Champney Park site was used, along with a site $4 \mathrm{~km}$ north on the Darien River (interconnected with the Altamaha River outflow; salinities ranging from 0 to about $15 \mathrm{psu}$ ). For cattail, sites were a non-tidal pond at the edge of a black needlerush (Juncus roemerianus) marsh near the Champney Park site, and a freshwater pond on Sapelo Island. For cabbage palm, the Champney Park site and the marsh edge near GCE Stn 3 on Sapelo 
Island were used. For the dune grasses, beach dunes just west of the surf zone were used, on Nannygoat Beach on the SE edge of Sapelo Island; the sites sampled were about $50 \mathrm{~m}$ apart (the 2 dune-grass species are intermingled on the dunes). Surface water from the Altamaha River was collected at the Champney Park site just after slack high tide (5 psu) for use in all subsequent incubations.

Collecting. For each plant species, 2 types of standing-decaying leaf blade were collected in May 2002: (1) dead leaves on living shoots (youngerdecaying); and (2) dead leaves on dead shoots (olderdecaying). For cabbage palm, single leaflets on a frond were collected, either as dead leaflets on partially living fronds, or from wholly dead fronds. Blades were cut at the ligule (except for cabbage palm), and portions $>10 \mathrm{~cm}$ distal to the ligule were cut away and discarded. At each site, 5 blades of each type were collected, each from a different shoot. Blades were kept dry and cool during transport to the laboratory, where they were stored air-dry at $23^{\circ} \mathrm{C}$ awaiting further processing (within $1 \mathrm{wk}$ ) (Newell 2001a).

$\mathrm{CO}_{2}$ release and organic mass. Lengths of $2 \mathrm{~cm}$ were cut from the ligule end of 3 blades of each species, type, and site; these ligule-including pieces were discarded. Lengths of $3 \mathrm{~cm}$ were then cut from the basal end of the 3 blades of each species, type, and site and pooled for measurement of $\mathrm{CO}_{2}$ release. Each piece was washed under running cold tapwater for $10 \mathrm{~s}$ to remove adherent material. Blade pieces were drained momentarily, and placed in $37 \mathrm{ml}$ serum vials, which had deionized water droplets adhering to the sides within the vials (for retention of $100 \%$ relative humidity). Blanks received no leaf material. Vials were sealed and incubated $2 \mathrm{~h}$ in darkness at $25^{\circ} \mathrm{C}$ to permit release of initial bursts of $\mathrm{CO}_{2}$ and to cause photosynthesis of epiphytic algae to cease (Newell et al. 1996). Vials were opened and resealed with serum stoppers following replacement of original air with standard air of known $\mathrm{CO}_{2}$ concentration. $\mathrm{CO}_{2}$ release was then measured during periods of linear rates of release in darkness at $25^{\circ} \mathrm{C}$ using infrared gas-analysis of headspace atmosphere as described by Newell et al. $(1985,1996)$, except that the instrument used for the present samples was a Capnicon Total $\mathrm{CO}_{2}$ Analyzer Model 5. Following $\mathrm{CO}_{2}$ measurement, the dry organic mass of each set of three $3 \mathrm{~cm}$ blade pieces was determined by microwave drying and ashing for $4 \mathrm{~h}$ at $450^{\circ} \mathrm{C}$ (Newell et al. 1995).

Ergosterol content. Lengths of $2 \mathrm{~cm}$ were cut from the basal end of the same 3 blades used for $\mathrm{CO}_{2}$ measurement for each species, site, and blade type, and these were used for measurement of ergosterol content. Ergosterol content is a proxy for living-fungal biomass (Newell 2001b, Gessner \& Newell 2002). Each 3 piece sample was placed in a $20 \mathrm{ml}$ screw-cap vial and $5 \mathrm{ml}$ of reagent ethanol was added to submerge the sample. The sample vials were stored at $4^{\circ} \mathrm{C}$ in darkness for a maximum of $2 \mathrm{wk}$. Ergosterol content of samples was measured using liquid chromatography as described by Newell (2001a,b, Gessner \& Newell 2002). Briefly, this involves methanolic reflux extraction, pentane partitioning of neutral lipids, and reverse-phase high-performance liquid chromatography.

Acetate incorporation into ergosterol. Three $2 \mathrm{~cm}$ pieces were cut from the basal end of the same 3 blades used for $\mathrm{CO}_{2}$ and ergosterol measurement, but only blades from smooth cordgrass, big cordgrass, and giant cutgrass were used to determine the rate of acetate incorporation into ergosterol. This rate is a proxy for rate of fungal biomass synthesis (Newell 2001b, Gessner \& Newell 2002). The sets of blade pieces were rinsed under cold running tapwater for $10 \mathrm{~s}$ to remove adherent material, drained, and placed in $20 \mathrm{ml}$ screw-cap vials (vials previously washed and dried at $100^{\circ} \mathrm{C}, 5 \mathrm{~h}$ ). Five $\mathrm{ml}$ of Altamaha River water (5 psu), collected at the Champney Park site, was added to each vial. The 5 psu incubation water was used as a compromise medium for all samples, to preclude differential influence of incubation salinities - note that decaying blades at all the sites experience ranges of salinity over periods of rainfall and tidal inundation. Just prior to use, the Altamaha water was vacuum-filtered through $0.2 \mu \mathrm{m}$ polycarbonate filters. The sample vials were loosely capped and incubated for $3 \mathrm{~h}$ on a slow-speed shaker (55 rpm; Innova shaker, New Brunswick Scientific) under $30 \mu \mathrm{E} \mathrm{m} \mathrm{m}^{-2} \mathrm{~s}^{-1}$ photosynthetically available radiation at $20^{\circ} \mathrm{C}$. These conditions were the same as those used to obtain conversion factors for this procedure (Newell 2001a,b). After $3 \mathrm{~h}$ of incubation for equilibration in the Altamaha water, $\left[1-{ }^{14} \mathrm{C}\right]$ acetate, sodium salt (ICN), was added along with non-radioactive sodium acetate to achieve a final concentration of $5 \mathrm{mM}$. Final specific activity was $4.94 \mathrm{DPM}^{\mathrm{DPol}}{ }^{-1}$ acetate. Incubation was continued as for the equilibration, for an additional $2 \mathrm{~h}$. Incorporation of acetate into ergosterol was determined according to Newell (2001a), except that the scintillation counter used was a Beckman LS6500.

Statistical analyses and conversion factors. A statistical-software package (SPSS/PC+ version 5.0; Norušis 1992) was used to process all data (1- and 2way analyses of variance, and regression). Angular or logarithmic transformations or Kruskal-Wallis nonparametric ANOVA were used for data with unequal 
variances, and Student-Newman-Keul's (SNK) method was used in testing least-significant ranges (Sokal \& Rohlf 1995). The word 'significant' is used herein exclusively to mean 'statistically significant' (probability of Type I error $<0.05$; Sokal \& Rohlf 1995). Means are shown below \pm 1 standard deviation (SD).

For rough conversion of ergosterol values to values for living-fungal mass, the factor 200 units fungal mass per unit ergosterol can be used (Gessner \& Newell 2002). For rough conversion of acetate-incorporation values to values for rate of fungal-mass synthesis, I suggest use of the factor $12.6 \mu \mathrm{g}$ fungal organic mass per nmol acetate incorporated; this is the factor found for ascomycetes of the smooth cordgrass standingdecay system, and it lies in the middle of the range of reported factors (Newell 2001a,b, Gessner \& Newell 2002).

\section{RESULTS}

\section{Site effect}

No significant effects of individual site sampled were found for any of the variables tested for each plant species (ANOVA, $\mathrm{p}>0.31$ to 0.94 ). Therefore, site data were pooled for all statistical analyses.

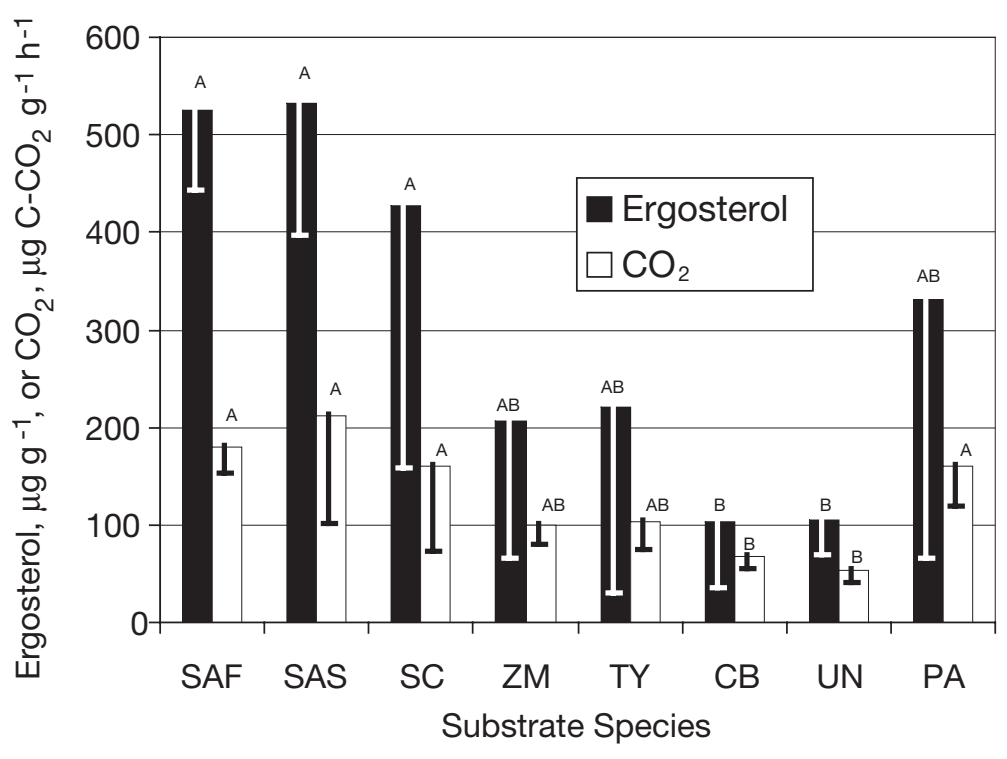

Fig. 1. Ergosterol content and rate of $\mathrm{CO}_{2}$ release (mean $\pm 1 \mathrm{SD}$ ) per g organic mass of standing-decaying leaf blades. Capital letters above bars for each variable indicate results of least-significant-range testing (SNK). The first 5 plant substrates to the left are marsh plants, with the more saline-adapted species to the left. The 3 plant substrates on the right are maritime terrestrial; the 2 dune grasses are the last 2 on the right. Plant species: $\mathrm{SAF}=$ smooth cordgrass at less-saline sites; $\mathrm{SAS}=$ smooth cordgrass at more saline sites; $\mathrm{SC}=$ big cordgrass; $\mathrm{ZM}=$ giant cutgrass; $\mathrm{TY}=$ cattail $\mathrm{CB}=$ cabbage palm; $\mathrm{UN}=$ sea oats; $\mathrm{PA}=$ seaside panicum

\section{Ergosterol content}

Mean ergosterol contents of leaf blades were significantly different among plant species $(p=0.0007)$, and ranged from $103 \pm 70 \mathrm{\mu g} \mathrm{g}^{-1}$ organic mass for cabbage palm to $532 \pm 84 \mathrm{\mu g} \mathrm{g}^{-1}$ for smooth cordgrass from saline sites (Fig. 1). There was no statistical difference between smooth cordgrass blades from highsalinity and low-salinity sites (Fig. 1). Average ergosterol content for older-decaying blades (all species, from dead shoots, $352 \pm 187 \mu^{\prime} g^{-1}$ ) was not significantly higher $(p=0.27)$ than that for younger-decay-

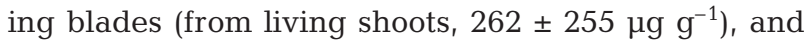
there was no significant interaction between plant species and blade age. There was a tendency for ergosterol content of blades to decline with freshness of marsh; when marsh freshness was assigned a rank, with 1 for most saline (smooth cordgrass), followed by 2 for big cordgrass, 3 for giant cutgrass, and 4 for freshest (cattail), there was a significant decline in the direction of freshwater $(\mathrm{r}=-0.59, \mathrm{p}=0.02)$. Two of the terrestrial plants, cabbage palm and sea oats, exhibited low ergosterol contents $\left(<110 \mathrm{\mu g} \mathrm{g}^{-1}\right)$, but one of the dune grasses (seaside panicum) had ergosterol content in its blades $\left(332 \pm 268 \mu \mathrm{g} \mathrm{g}^{-1}\right)$ that was not significantly different from that of smooth cordgrass (Fig. 1).

It should be noted here that ergosterol content of 1 sample of big cordgrass was a high outlier $\left(833 \mu \mathrm{g} \mathrm{g}^{-1}\right.$; the remaining 3 samples averaged only $290 \mu^{-1} \mathrm{~g} \mathrm{~g}^{-1}$; see Fig. 1). The outlier sample was anomalously low in organic mass (i.e. the blades were exceptionally thin and small). Samples of small, light blades tended to have high ergosterol contents when data for all species were pooled $(\mathrm{r}=-0.51$ for organic mass versus ergosterol content, $\mathrm{p}=0.003$ ).

\section{$\mathrm{CO}_{2}$ release}

Rates of $\mathrm{CO}_{2}$ release per unit decaysystem mass were significantly different among plant species $(p=0.0001$; Fig. 1$)$, but not between blade ages, and there was no significant interaction $(p=0.26)$ between these 2 factors. There was a clear parallel between outcomes for ergosterol content and for $\mathrm{CO}_{2}$ release, and the 2 variables were significantly correlated $(\mathrm{r}=$ $0.77, \mathrm{p}<0.0001$ ), but rate of $\mathrm{CO}_{2}$ release was not significantly correlated with rate of acetate incorporation into ergosterol per unit ergosterol nor with acetate incorpora- 
tion per unit organic mass $(r=-0.26$ and 0.27 respectively, $\mathrm{p}>0.31$; see next section). Microbes within the salt-adapted spartinas (both species) respired at the highest rates per unit decaying-system mass, but 1 of the dune grasses (seaside panicum) had equivalent respiration rates (>150 $\mathrm{ug} \mathrm{g}^{-1}$ organic mass $\mathrm{h}^{-1}$; Fig. 1). There was no significant difference among plant species in hourly $\mathrm{CO}_{2}$ release per unit ergosterol (overall mean =

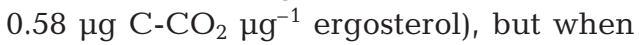
the data for the spartinas were pooled and tested against the remaining species, the spartinas were significantly $(\mathrm{p}=0.01)$ lower (spartinas, $0.38 \mu \mathrm{g} \quad \mathrm{C}-\mathrm{CO}_{2} \quad \mu g^{-1}$ ergosterol; other species, $0.70 \mu \mathrm{g}^{-1}$ ).

\section{Acetate incorporation}

Mean rates of acetate incorporation into ergosterol, per unit ergosterol, varied in an opposing direction to the trend found for ergosterol content; i.e. there was an increase ( $p=0.04$ ) from more- to less-salineadapted grasses (Fig. 2). There was no significant interaction between grass species and age of standing-decaying blades, but younger blades averaged about 2.5-fold greater than older blades ( $\mathrm{p}=$ 0.03 ; Fig. 2). Rate of acetate incorporation per unit ergosterol was inversely correlated with ergosterol content of blades ( $r=-0.64, p=0.008)$.

Although mean rates of acetate incorporation per unit mass of decaying blade were lowest for olderdecaying smooth cordgrass $\left(5.3 \pm 1.6 \mathrm{pmol} \mathrm{mg}^{-1}\right.$ organic mass $\mathrm{h}^{-1}$ ) and highest for younger-decaying

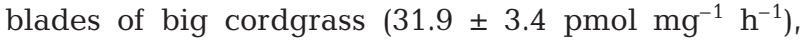
there was no significant difference among rates of acetate incorporation per unit mass $(p=0.12)$, with the grand mean being $15.1 \pm 8.2 \mathrm{pmol} \mathrm{mg}^{-1} \mathrm{~h}^{-1}$. Rate of acetate incorporation per unit mass was not significantly correlated with ergosterol content of decaying blades $(r=0.10, p=0.70)$.

The ratio of $\mathrm{CO}_{2}$ release rate per gram decay system mass to rate of acetate incorporation per mg system mass (an inverse index of efficiency of production) was significantly different among plant species $(p=0.007)$, but not between ages of decaying blades ( $p=0.18)$. Smooth cordgrass from fresher-water sites and the 2 brackish/fresh plants (big cordgrass and giant cutgrass) had ratios in a statistically homogeneous low group $(13.9 \pm 6.9,9.1 \pm 3.9$, and $6.6 \pm 0.8$, respectively). Smooth cordgrass from saltier sites had a significantly higher mean ratio of $24.7 \pm 9.5$.

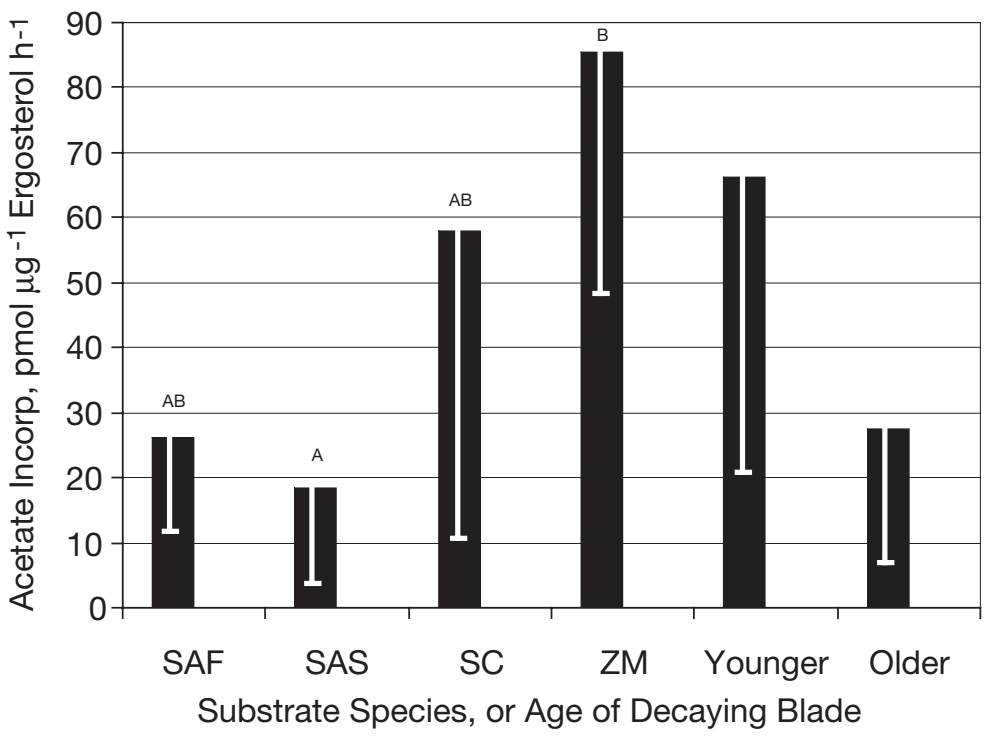

ig. 2. Rate of incorporation of radiolabeled acetate into ergosterol within standing-decaying leaf blades, per unit ergosterol (mean $\pm 1 \mathrm{SD}$ ). Capital testing (SNK). Plant species: SAF = smooth cordgrass at less-saline = giant cutgrass. 'Younger' $=$ decaying blades from living shoots, S, SC and ZM; 'Older' = decaying blades from wholly dead shoots (category means significantly different)

\section{DISCUSSION}

Surveying marsh plants with prominent standingdecaying leaf blades did seem to corroborate the previously obtained suggestion of decreasing accumulation of living-fungal mass moving from saltmarsh plants to freshwater marsh plants (Newell et al. 1995 vs Newell 2001a,c) - in the current work, decaying blades of saltmarsh cordgrass exhibited more than twice the ergosterol contents that the most freshwateradapted plants had (giant cutgrass, cattail) (Fig. 1). Findlay et al. (2002a) measured ergosterol concentrations in standing-decaying blades of 2 marsh plants in a NE USA freshwater system (Hudson River, cattail Typha angustifolia and common reed Phragmites australis), and compared their findings to previously reported ergosterol contents of other standing-decaying leaves. The Hudson River plants, during their standing-decaying stages, contained ergosterol at average levels below those of our lowest freshwater samples (<150 $\mathrm{\mu g} \mathrm{g}^{-1}$ system mass; cf. Fig. 1), strengthening the hypothesis that freshwater marsh plants tend to support lower accumulations of living-fungal mass in standing-decaying leaves relative to saltmarsh plants.

Consistent with the hypothesis of decreasing content of living-fungal mass in standing-decaying blades from saltmarsh to freshwater marsh are the reports of 
Castro \& Freitas (2000) of average ergosterol contents up to $625 \mu \mathrm{g} \mathrm{g}^{-1}$ in winter for standing-decaying leaves of saltmarsh grass Spartina maritima in Portugal, a range of mean ergosterol contents for standing-decaying blades of smooth cordgrass $S$. alterniflora from saltmarshes from Florida to Maine of 337 to $632 \mu \mathrm{g} \mathrm{g}^{-1}$ (Newell et al. 2000), and average ergosterol contents for mid-portions of standing-decaying leaves of freshwater cattail Typha latifolia of $\leq 100 \mu \mathrm{g} \mathrm{g}^{-1}$ (Bärlocher \& Biddiscombe 1996) and average ergosterol content in standing-decaying leaf blades of common reed at Lake Belau of $<250 \mathrm{\mu g} \mathrm{g}^{-1}$ (Gessner 2001). Less supportive of the hypothesis from the saltmarsh view are the reports of Newell (2001c) for saltmarsh black needlerush (mean values for 2 older categories of standing-decaying blades of 259 to $308 \mu \mathrm{g} \mathrm{g}^{-1}$ ) and Samiaji \& Bärlocher (1996) for smooth cordgrass from the northern limit of its range (mean values for standing-decaying

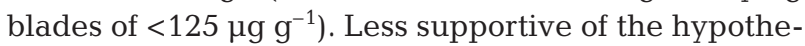
sis from the freshwater marsh view are the reports of Kuehn \& Suberkropp (1998a) for soft rush Juncus effusus (mean ergosterol contents of standing-decaying blades of 229 to $422 \mu \mathrm{g} \mathrm{g}^{-1}$ ), Kuehn et al. (1999) for giant plumegrass Erianthus giganteus (mean ergosterol contents of standing- decaying blades of 109 to $336 \mu \mathrm{g} \mathrm{g}^{-1}$ ), and Gessner (2001) for common reed Phragmites australis (mean ergosterol content of standing-decaying leaves from low on shoots at Lake Alpnach of 202 to $403 \mu \mathrm{g} \mathrm{g}^{-1}$; but note that for leaves at mid- to upper-canopy heights, mean contents were $<200 \mu \mathrm{g} \mathrm{g}^{-1}$ ).

The lowest mean values for ergosterol contents of standing-decaying leaf blades in the present series were those of terrestrial plants (sea oats and cabbage palm, ca. $100 \mathrm{\mu g} \mathrm{g}^{-1}$; Fig. 1). However, a third terrestrial plant, growing mixed with the sea oats on sand dunes, had mean ergosterol contents of standingdecaying blades of over $300 \mu \mathrm{g} \mathrm{g}^{-1}$ (seaside panicum, Fig. 1), so no conclusion is yet possible regarding positioning of terrestrial standing-decaying leaves in the continuum of ergosterol contents from saltmarsh through freshwater marshes to terrestrial situations. Note that terrestrial leaves decaying after deposit in freshwater streams have exhibited a wide range of ergosterol contents (e.g. Paul \& Meyer 1996: means of ca. $25 \mathrm{\mu g} \mathrm{g}^{-1}$ for maple leaves, and zero for rhododendron leaves, but as high as $555 \mathrm{\mu g} \mathrm{g}^{-1}$ for tulip poplar; Suberkropp 2001: maximum means of 587 to $714 \mu \mathrm{g}$ $\mathrm{g}^{-1}$ for tulip poplar and white oak; Findlay et al. 2002b: overall mean for mixed leaves of $83 \mu \mathrm{g} \mathrm{g}^{-1}$; see also Table 2 of Gessner 1997).

Rates of $\mathrm{CO}_{2}$ release from standing-decaying leaf blades were strongly correlated with content of livingfungal mass $\left(\mathrm{r}^{2}=0.59\right)$, as one would expect, given that the great bulk of microbial mass in/on the blades is composed of fungal structures (pervading mycelia and ascomata; e.g. Newell et al. 1996, Kuehn et al. 2000, Newell \& Porter 2000, Findlay et al. 2002a). But interestingly, rates of $\mathrm{CO}_{2}$ release were not significantly correlated with rates of ergosterol synthesis $\left(r^{2}=0.07\right)$. One potential explanation for this is that at any one point in the decay process, fungal activity is variably composed of mycelial growth (with variable growth efficiency), lignocellulose digestion, ascomatal maturation, etc., and not all of these would involve synthesis of new ergosterol-containing membranes to the same extent. The fact that there was a trend downward in the ratio between $\mathrm{CO}_{2}$ release and acetate incorporation, moving from saltmarsh to freshwater marsh blades, might mean that in the blades with high content of living-fungal mass, the fungi were having to expend more energy per unit new fungal mass produced. Perhaps this was a consequence of fungi having to respire more during lysis of the remaining, most digestion-resistant plant polymers, especially when having to produce compatible solutes to cope with saltiness.

It has been hypothesized that following standingdecay (or early submerged-decay for fallen riparian leaves), leaves of plants such as smooth cordgrass Spartina alterniflora would fragment naturally to the sediment, where they would enter a bacterial/ meiofaunal-driven decay process (e.g. Newell \& Palm 1998, Newell \& Porter 2000, Baldy et al. 2002, Findlay et al. 2002b). However, Newell et al. (1995) found highest ergosterol contents in naturally broken, fallen leaf blades of Walter's sedge Carex walteriana in a freshwater swamp, and several recent reports have also shown rising ergosterol content in leaves on freshwater sediments as opposed to the ergosterol content prior to leaf collapse onto the sediment (e.g. for common reed, soft rush, and cattail: Komínková et al. 2000, Kuehn et al. 2000, Findlay et al. 2002a). This rise in accumulation of fungal mass in fallen blades of standing-decaying shoots may be consistent with the current findings of higher activity $\left(\mathrm{CO}_{2}\right.$ release, acetate incorporation into ergosterol) per unit living-fungal mass (as ergosterol) for the plants with lower ergosterol contents (Figs. 1 \& 2). Perhaps the fungi in standing-decaying blades of fresher-water systems are more limited than the saltwater species in the extent to which they can grow during the standing-dead stage, yet they are poised to grow quickly upon release from limitation. Deposition on the more persistently wet sediment surface (exposed during ebb tides, but always damp) might constitute such a release (simulated by the current submerged incubations), allowing rapid accumulation of living-fungal mass.

Why there should be more limited fungal growth and/or fungal accumulation in the fresher-water and 
terrestrial standing-decaying blades is not clear. One obvious difference between the smooth cordgrass in the saltmarsh and the fresher-water marsh plants is that mycophagous, leaf-shredding invertebrates (periwinkles, amphipods, crabs: Graça et al. 2000, Newell \& Porter 2000) are more prominent in the saltmarsh canopy than in the fresher marshes (S. Newell pers. obs.). Although the shredders in the saltmarsh could clearly have positive effects upon the fungi (e.g. nitrogen recycling via fecal deposits: Graça et al. 2000), this factor was absent in the submerged incubations conducted in this work. Also, 1 of the smooth cordgrass stations was located in a mostly freshwater site, where the saltmarsh shredders were absent, and this had no clear effect upon fungal activity (except potentially the ratio of respiration to production, which was lower at the freshwater site).

It has been postulated that release of fungi from water-availability limitation in standing-decaying blades of smooth cordgrass is largely due to formation of dew; although tides and rain also perform this function, dew is the longest-lasting wetting phenomenon (Newell et al. 1998). Dew is also an important wetting phenomenon for standing-decaying blades of freshwater macrophytes (Kuehn \& Suberkropp 1998b). Since there would not appear to be a difference in dew formation between adjacent freshwater marsh and saltmarsh ecosystems, the limitation of fungi in freshwater leaves may be a consequence of response of particular types of decaying blades to dewset. It is known that different parts of dead shoots of smooth cordgrass respond differently to wetting, with respect to subsequent mitigating of activity-restricting negative water potential $(\Psi)$, and consequent diminishing of water-availability stress (Newell et al. 1991). Leaf blades exhibited more rapid reduction of $\Psi$ than the more lignified stems (power curve exponents, $\Psi$ vs water content, blades $=-1.69$; stems $=-0.68)$. I hypothesize that the lower fungal accumulations of living-fungal mass found for the fresher-water macrophytes in the current work are at least a partial consequence of less time in the marsh, during which fungal activity is enabled by favorable $\Psi$, due to less responsiveness of $\Psi$ to dewset. This hypothesis is supported by the finding that the fungi within the freshwater-decaying blades in the current work were able to respond strongly after full freshwater saturation $\left(\mathrm{CO}_{2}\right.$ incubations) and after complete submergence in 5 psu seawater (acetate incubations), and were able to exhibit high activity per unit living-fungal mass (Figs. 1 \& 2). The same hypothesis would apply to the terrestrial leaf blades of the current work, and might explain the relatively high livingfungal accumulations found for seaside panicum - perhaps this grass has low-lignin blades (and less cuticular hydrophobicity?) that respond relatively strongly to dewset. The comparison between stiffness of the blades of sea oats (stiff) and seaside panicum (more flexible) is consistent with this hypothesis ( $\mathrm{S}$. Newell pers. obs.). For the freshwater macrophytes, this hypothesis would then explain the increases seen in accumulation of livingfungal mass soon after collapse of blades to the wetter sediment surface: $\Psi$ would be permanently more favorable on the wet marsh floor. Perhaps the transition to bacterial/meiofaunal dominance of the decay process, following fall of standing-decaying leaves, is routinely delayed by a burst of fungal activity in some systems, as internally established fungal pervaders find persistently favorable water-availability conditions.

It does appear that saltmarsh cordgrass is characterized by uniquely high accumulations of living-fungal mass among standing-decay systems, although high exceptions exist to what appear to be generally low accumulations for freshwater and terrestrial standingdecay systems. I hypothesized above that this is at least partially due to high susceptibility to wetting by dew. Other possible contributors are: (1) the positive effects of non-intense grazing upon decaying leaves by invertebrates (Graça et al. 2000, Newell 2001a); (2) high rates of input of phosphorus from marsh sediments during tidal flooding (Newell 2001a); (3) high rates of nitrogen fixation by prokaryotic epiphytes, probably including Azospirillum species (Newell et al. 1992, Lovell et al. 2001); (4) mutualism with everpresent epiphytic green microalgae (Newell \& Porter 2000); (5) access to high levels of sulfate in tidal flooding waters. In spite of the high rates of fungal accumulation that occur during the standing-decaying phase, it has recently been found that when the standingdecaying blades of smooth cordgrass collapse to the sediment surface, there can be a decrease in livingfungal content of the blades. However, this decrease does not always occur; it has not been found to be greater than 2-fold, and a concurrent shifting in ascomycete community structure takes place, indicating strongly that ascomycetes continue to be active at the collapsed-on-sediment stage (Buchan et al. 2002, unpubl.).

Acknowledgements. This research was supported by grants from the US National Science Foundation (OCE 9982133 and 9521588). It is a portion of the work of the Decomposer Consortia Experimental Group (E. Biers, A. Buchan, R. Hodson, J. Hollibaugh, M. Moran, J. Moreta, S. Newell) within the GCE/LTER Program (http://gce-lter.marsci.uga.edu/lter/). This is Contribution 916 of the University of Georgia Marine Institute. 


\section{LITERATURE CITED}

Baldy V, Chauvet E, Charcosset JY, Gessner MO (2002) Microbial dynamics associated with leaves decomposing in the mainstem and floodplain pond of a large river. Aquat Microb Ecol 28:25-36

Bärlocher F, Biddiscombe NR (1996) Geratology and decomposition of Typha latifolia and Lythrum salicaria in a freshwater marsh. Arch Microbiol 136:309-325

Buchan A, Newell SY, Moreta JIL, Moran MA (2002) Analysis of internal transcribed spacer (ITS) regions of rRNA genes in fungal communities in a southeastern US salt marsh. Microb Ecol 43:329-340

Castro P, Freitas H (2000) Fungal biomass and decomposition in Spartina maritima leaves in the Mondego salt marsh (Portugal). Hydrobiologia 428:171-177

Duncan WH, Duncan MB (1987) Seaside plants of the Gulf and Atlantic coasts. Smithsonian Institution Press, Washington, DC

Findlay SEG, Dye S, Kuehn KA (2002a) Microbial growth and nitrogen retention in litter of Phragmites australis compared to Typha angustifolia. Wetlands 22:616-625

Findlay SEG, Tank J, Dye S, Valett HM and 7 others (2002b) A cross-system comparison of bacterial and fungal biomass in detritus pools of headwater streams. Microb Ecol 43:55-66

Gessner MO (1997) Fungal biomass, production and sporulation associated with particulate organic matter in streams. Limnetica 13:33-44

Gessner MO (2001) Mass loss, fungal colonisation and nutrient dynamics of Phragmites australis leaves during senescence and early aerial decay. Aquat Bot 69:325-339

Gessner MO, Newell SY (2002) Biomass, growth rate, and production of filamentous fungi in plant litter. In: Hurst CJ, Crawford RL, McInerney M, Stetzenbach L, Knudsen G (eds) Manual of environmental microbiology, 2nd edn. ASM Press, Washington, DC, p 390-408

Graça MAS, Newell SY, Kneib RT (2000) Grazing rates of organic matter and living fungal biomass of decaying Spartina alterniflora by three species of saltmarsh invertebrates. Mar Biol 136:281-289

Kneib RT (2000) Salt marsh ecoscapes and production transfers by estuarine nekton in the southeastern United States. In: Weinstein MP, Kreeger DA (eds) Concepts and controversies in tidal marsh ecology. Kluwer Academic, Dordrecht, p 267-291

Kohlmeyer J, Volkmann-Kohlmeyer B (2002) Fungi on Juncus and Spartina: new marine species of Anthostomella, with a list of marine fungi known on Spartina. Mycol Res 106: 365-374

Komínková D, Kuehn KA, Büsing N, Steiner D, Gessner MO (2000) Microbial biomass, growth, and respiration associated with submerged litter of Phragmites australis decomposing in a littoral reed stand of a large lake. Aquat Microb Ecol 22:271-282

Kuehn KA, Suberkropp K (1998a) Decomposition of standing litter of the freshwater emergent macrophyte Juncus effusus. Freshw Biol 40:717-727

Kuehn KA, Suberkropp K (1998b) Diel fluctuations in rates of $\mathrm{CO}_{2}$ evolution from standing dead leaf litter of the emergent macrophyte Juncus effusus. Aquat Microb Ecol 14: 171-182

Kuehn KA, Gessner MO, Wetzel RG, Suberkropp K (1999) Decomposition and $\mathrm{CO}_{2}$ evolution from standing litter of the emergent macrophyte Erianthus giganteus. Microb Ecol 38:50-57

Kuehn KA, Lemke MJ, Suberkropp K, Wetzel RG (2000)
Microbial biomass and production associated with decaying leaf litter of the emergent macrophyte Juncus effusus. Limnol Oceanogr 45:862-870

Lovell CR, Friez MJ, Longshore JW, Bagwell CE (2001) Recovery and phylogenetic analysis of nifH sequences from diazotrophic bacteria associated with dead aboveground biomass of Spartina alterniflora. Appl Environ Microbiol 67:5308-5314

Newell SY (2001a) Multiyear patterns of fungal biomass dynamics and productivity within naturally decaying smooth cordgrass shoots. Limnol Oceanogr 46:573-583

Newell SY (2001b) Fungal biomass and productivity. In: Paul JH (ed) Methods in microbiology, Vol 30. Marine microbiology. Academic Press, New York, p 357-372

Newell SY (2001c) Fungal biomass and productivity in standing-decaying leaves of black needlerush (Juncus roemerianus). Mar Freshw Res 52:249-255

Newell SY (2002) Fungi in marine/estuarine waters. In: Bitton G (ed) The encyclopedia of environmental microbiology. John Wiley, New York, p 1394-1400

Newell SY, Palm LA (1998) Responses of bacterial assemblages on standing-decaying blades of smooth cordgrass to additions of water and nitrogen. Int Rev Hydrobiol 83: 115-122

Newell SY, Porter D (2000) Microbial secondary production from saltmarsh grass shoots, and its known and potential fates. In: Weinstein MP, Kreeger DA (eds) Concepts and controversies in tidal marsh ecology. Kluwer Academic, Dordrecht, p 159-185

Newell SY, Fallon RD, Cal Rodriguez RM, Groene LC (1985) Influence of rain, tidal wetting and relative humidity on release of carbon dioxide by standing-dead salt-marsh plants. Oecologia 68:73-79

Newell SY, Arsuffi TL, Kemp PF, Scott LA (1991) Water potential of standing-dead shoots of an intertidal grass. Oecologia 85:321-326

Newell SY, Hopkinson CS, Scott LA (1992) Patterns of nitrogenase activity (acetylene reduction) associated with standing decaying shoots of Spartina alterniflora. Estuar Coast Shelf Sci 35:127-140

Newell SY, Moran MA, Wicks R, Hodson RE (1995) Productivities of microbial decomposers during early stages of decomposition of leaves of a freshwater sedge. Freshw Biol 34:135-148

Newell SY, Porter D, Lingle WL (1996) Lignocellulolysis by ascomycetes (Fungi) of a saltmarsh grass (smooth cordgrass). Microsc Res Technol 33:32-46

Newell SY, Arsuffi TL, Palm LA (1998) Seasonal and vertical demography of dead portions of shoots of smooth cordgrass in a south-temperate saltmarsh. Aquat Bot 60: 325-335

Newell SY, Blum LK, Crawford RE, Dai T, Dionne M (2000) Autumnal biomass and potential productivity of saltmarsh fungi from $29^{\circ}$ to $43^{\circ}$ north latitude along the United States Atlantic Coast. Appl Environ Microbiol 66:180-185

Norušis MJ (1992) SPSS/PC+. Base system user's guide, Version 5. SPSS, Chicago

Paul MJ, Meyer JL (1996) Fungal biomass of 3 leaf litter species during decay in an Appalachian stream. J N Am Benthol Soc 15:421-432

Samiaji J, Bärlocher F (1996) Geratology and decomposition of Spartina alterniflora Loisel in a New Brunswick saltmarsh. J Exp Mar Biol Ecol 201:233-252

Scavia D, Field JC, Boesch DF, Buddemeier RW and 10 others (2002) Climate change impacts on US coastal and marine ecosystems. Estuaries 25:149-164

Smith C, Alber M, Sheldon JE (2001) Linking shifts in historic 
estuarine vegetation to salinity changes using a GIS. In: Hatcher KJ (ed) Proc 2001 Georgia Water Resources Conf. Institute of Ecology, University of Georgia, Athens, p 615-618

Sokal RR, Rohlf FJ (1995) Biometry, 3rd edn. WH Freeman, New York

Suberkropp K (2001) Fungal growth, production, and sporulation during leaf decomposition in two streams. Appl Environ Microbiol 67:5063-5068

Teal JM, Howes BL (2000) Salt marsh values: retrospection from the end of the century. In: Weinstein MP, Kreeger DA (eds) Concepts and controversies in tidal marsh ecology. Kluwer Academic, Dordrecht, p 9-19

Editorial responsibility: Kevin Carman, Baton Rouge, Louisiana, USA
Tiner RW (1993) Field guide to coastal wetland plants of the southeastern United States. University of Massachusetts Press, Amherst

Turner RE, Boesch DF (1988) Aquatic animal production and wetland relationships: insights gleaned following wetland loss or gain. In: Hook DD (ed) The ecology and management of wetlands. Croom Helm, London, p 25-39

Zimmerman RJ, Minello TJ, Rozas LP (2000) Saltmarsh linkages to productivity of penaeid shrimps and blue crabs in the northern Gulf of Mexico. In: Weinstein MP, Kreeger DA (eds) Concepts and controversies in tidal marsh ecology. Kluwer Academic, Dordrecht, p 293-314

Submitted: September 25, 2002; Accepted: December 18, 2002 Proofs received from author(s): March 24, 2003 